\title{
The essence and implementation of the organizational and economic mechanism management of agricultural enterprises: theoretical aspect
}

\author{
E. A. Farvazova ${ }^{1 凶}$ \\ ${ }^{1}$ Ural State Agrarian University, Ekaterinburg, Russia \\ 凶-mail: linulya07@mail.ru
}

\begin{abstract}
Purpose. The study of the concepts of organizational and economic mechanism of management of agricultural enterprises, methodological approaches to its structure and evaluation of implementation. Methods. The views of domestic and foreign scientists on the content, composition and evaluation of indicators of the organizational and economic mechanism are analyzed. In the course of theoretical and methodological research, a systematic approach was applied using methods of comparative analysis, graphical, abstract-logical, methods of comparison, analogy and generalization. Results. Based on the consideration and synthesis of the concepts of the model study of organizational-economic mechanism, as well as their own conclusions, the proposed elements of the mechanism of agricultural enterprises where the central place is occupied by the state regulation and support of agrarian sector, and also included an additional element - the digitalization of the industry. Comparing positions of scientists concerning the analysis of realization of the mechanism of managing, the author draws a conclusion concerning existence of the indicators characterizing only a financial condition and stability of the agricultural enterprises which concern an organizational and economic component of the mechanism. The scientific novelty consists in the correction of the diagnostic model of the organizational and economic mechanism, according to which the integral indicator of the efficiency of the economic mechanism is calculated on the example of agricultural enterprises and organizations of the Zauralya. The study of the elements and the proposed assessment model of the organizational and economic mechanism of management are the subject to a single goal-competent adjustment of the mechanism levers by both state bodies and economic entities themselves for the successful development of farmers in modern economic conditions.
\end{abstract}

Keywords: organizational and economic mechanism, levers, agricultural producers, agricultural production, evaluation, efficiency.

\section{Introduction}

In modern economic conditions for Russian agricultural producers there is an acute problem not only the growth of all agricultural production, but also resource support, support for employment of workers, taxation and subsidies to farmers. To solve all these issues requires the construction of an effectively functioning system of organizational and economic mechanisms of regional agro-industrial complexes (hereinafter-agribusiness) management. The modern management mechanism should correspond to changing market conditions allow agricultural producers to function effectively within the framework of the agricultural policy of each subject of the Russian Federation and be based on the optimal combination of different, but interrelated elements [1, p. 24].

In the scientific literature, analytical studies presented a wide review of different approaches and interpretations of the concept of "organizational and economic mechanism", however, many scientists characterize this term as a fundamental economic category $[2$, p. $8 ; 3$, p. $116 ; 4$, p. 306]. The problem of formation and development of the organizational and economic relations system between economic entities is the subject of both theoretical and practical research in agricultural science, which is due to the presence of many concepts, hypotheses, points of view, forming methods of economic diagnostics of organizational and economic mechanisms.
The most general characteristics of the presented economic category are investigated and presented in the works of foreign authors, such as A. Kulman [5, p. 18], Ya. Feriants [6, p. 61], L. Hurwitz [7, p. 281], M. Friedman [8, p. 14], and domestic ones - L. I. Abalkin [9, p. 92], Yu. M. Osipov, P. G. Bunich [10, p. 13], B. A. Raisberg, O. V. Fedorovich [11, p. 214] and others. In their studies, the organizational-economic mechanism is considered as a multi-level, multidimensional economic phenomenon, mainly related to the macroeconomic level, but the mechanism of subsystems of the lower level has not been studied. Questions of the composition and structure of economic mechanisms are reflected in the works of D. V. Khodos [12, p. 82], O. S. Gorbunova [13, p. 57], N. A. Belikova [14, p. 11], however, each author presents his own set of the mechanism, blocks and components included in the system, and they do not take into account fundamentally new elements corresponding to modern conditions of the market economy. In addition, not all studies on this topic take into account the structure of the organizational and economic mechanism of state regulation system and supporting of agriculture. From our point of view, the current situation of terminological plurality regarding the concept, composition, meaning of economic mechanisms occurs as a result of several facts. Firstly, this category is considered by scientists from the standpoint of different conceptual economic theories. Secondly, it is ap- 
plied to different social and political formations and thirdly, different methods and methodologies are used in the research of this category. Thus, despite a sufficient number of different studies conducted both at the world and domestic levels, this problem is quite relevant and requires further study.

\section{Methods}

Theoretical and methodological research includes the collection and analysis of economic information, statistical data and method of graphical interpretation. The empirical base is studying of domestic and foreign scientists works learning the formation and implementation of the organizational and economic mechanism of management. The basis for the calculations was the official statistical data of the Department of agriculture of the Kurgan region. For realization of the set tasks concerning studying of functioning of system of the given mechanism the system approach, and also various qualitative and quantitative methods, such as a method of the comparative analysis, graphic, abstract-logical, methods of comparison, analogies and generalization was applied.

On the basis of consolidated accounting (financial) statements of agricultural enterprises and organizations in the Kurgan region was expected and analyzed the indicators of efficiency of organizational-economic mechanism of management, determine the possibility of implementing each of the components of the mechanism.

\section{Results}

The agro-industrial complex of the Kurgan region, as well as many other agricultural regions of Russia, is one of the leading sectors of the region's economy, forming the food and economic security of the region. However, the influence of some negative factors, such as the high dependence of agricultural production on climatic conditions, slow capital turnover, underdevelopment of rural infrastructure, are reflected in the current state of agricultural production, which is currently characterized by instability [15, p. 130]. In 2018, there is an increase in the volume of gross agricultural output by $6 \%$ compared to the previous year, but the dynamics of certain indicators in crop production and animal husbandry remains negative. Thus, the acreage of all agricultural crops decreased by $2 \%$ and amounted to 1338.3 thousand hectares in 2018, the number of all types of farm animals decreased, and their productivity indicators decreased [16]. The existing problems of the development of the agrarian regional industry require a comprehensive solution of many issues by optimizing the organizational and economic mechanism, which is acting on the agro-industrial complex.

In the works of most scientists it is said that this mechanism is formed at all levels of management-macro, meso-level and micro-level, while at each level of management the mechanism performs certain functions corresponding to the goals of its existence [17, p. $380 ; 18$, p. 5456; 19, p. 31].

Table 1

Description of approaches to the interpretation of the concept, composition and evaluation of indicators of the organizational and economic mechanism

\begin{tabular}{|c|c|c|}
\hline Definition & $\begin{array}{c}\text { Mechanism blocks, structural } \\
\text { elements }\end{array}$ & Evaluation indicators \\
\hline \multicolumn{3}{|c|}{ D. A. Korobeinikov, D. N. Telitchenko [21, p. 37] } \\
\hline $\begin{array}{l}\text { It is a system of organizational and } \\
\text { economic relations, including a self- } \\
\text { regulatory system of functioning and } \\
\text { interaction of agricultural producers of } \\
\text { various organizational and legal forms }\end{array}$ & $\begin{array}{l}\text { 1. Subjects of management (state, re- } \\
\text { gional, sectoral and economic level). } \\
\text { 2. Control object. } \\
\text { 3. Risky market environment }\end{array}$ & $\begin{array}{l}\text { Indicators of the financial condition of } \\
\text { agricultural enterprises }\end{array}$ \\
\hline \multicolumn{3}{|c|}{ K. A. Mikov [22, p. 120] } \\
\hline $\begin{array}{l}\text { It is a developing, open system consist- } \\
\text { ing of interconnected and mutually } \\
\text { reinforcing elements implemented at } \\
\text { different levels }\end{array}$ & $\begin{array}{l}\text { 1. Elements used in the framework of the } \\
\text { system of relations in agriculture: lend- } \\
\text { ing, taxation, insurance, etc. } \\
\text { 2. Elements applied at the organization } \\
\text { (enterprise) level: business plan, con- } \\
\text { trolling, budgeting and others }\end{array}$ & $\begin{array}{l}\text { Assessment indicators of sustainable } \\
\text { development of regional agriculture, } \\
\text { divided into five local information } \\
\text { modules }\end{array}$ \\
\hline \multicolumn{3}{|c|}{ V. A. Borovinskikh, T. N. Medvedeva [23, p. 9] } \\
\hline $\begin{array}{l}\text { Is the set of organizational elements of } \\
\text { farming with the help of economic levers } \\
\text { aimed at improving the efficiency of ag- } \\
\text { ricultural enterprises }\end{array}$ & $\begin{array}{l}\text { 1. Elements of organizational nature: } \\
\text { organizational and legal status of the } \\
\text { organization, management technology, } \\
\text { etc. } \\
\text { 2. Elements of economic character: fi- } \\
\text { nancing, rationing, investment, etc. }\end{array}$ & $\begin{array}{l}\text { 1. Indicators of economic efficiency of } \\
\text { the mechanism (profitability of sales, } \\
\text { coverage ratio, coefficient of autonomy } \\
\text { and others). } \\
\text { 2. Indicators of organizational efficien- } \\
\text { cy of the mechanism (profitability ratio } \\
\text { of management, return on capital and } \\
\text { others) }\end{array}$ \\
\hline \multicolumn{3}{|c|}{ E. V. Ginter [24, p. 43] } \\
\hline $\begin{array}{l}\text { It is a complex of economic levers, in- } \\
\text { cluding administrative, legal, economic } \\
\text { and organizational components }\end{array}$ & $\begin{array}{l}\text { Elements of macroeconomic, micro- } \\
\text { economic (budget support, lending, } \\
\text { taxation, etc) and microeconomic (or- } \\
\text { ganizational and legal form, size and } \\
\text { specialization, etc) level }\end{array}$ & $\begin{array}{l}\text { 1. Cost recovery level. } \\
\text { 2. The coefficient of autonomy. } \\
\text { 3. Current liquidity ratio. } \\
\text { 4. The ratio of security of own working } \\
\text { capital. } \\
\text { 5. Financial independence ratio. }\end{array}$ \\
\hline
\end{tabular}


Considering the implementation of the organizational and economic mechanism of management of agricultural enterprises, it is necessary to pay attention to its constituent elements and their functioning [20, p. 91512]. Having studied the approaches of a number of scientists to assess the effectiveness of economic mechanisms of agricultural enterprises and existing models of building their system, we have generalized and systematized the presented provisions (table 1).

In the structure of any organizational and economic mechanism of management, the relationship between its elements of the mechanism are key, since they unite all its constituent parts, and are also responsible for the work of the entire mechanism-from setting goals to achieving results. The conducted researches allow to draw a conclusion that authors, basically, the characteristic of organizational and economic blocks of the mechanism is given and at a complex assessment of efficiency of such mechanism indicators of a financial condition and stability of subjects of managing are applied, as a rule.

From our point of view, as the main element of the mechanism, it is necessary to allocate the system of state support for agriculture, since the implementation of programs in the field of agricultural policy is aimed at achieving the goals of the functioning of the organizational and economic mechanism of management of agricultural enterprises, such as improving the efficiency and sustainability of agricultural production, minimizing risks and others (fig. 1).

Among the directions of state regulation of the industry, the author additionally introduced such a new element as the digitalization of agricultural production, as it is the most important component of modern, corresponding to world standards, agriculture.

In the framework of this work, the previously conducted author's research has been refined for the purpose of high information content and clarity of the presented materials while maintaining the simplicity of calculations. From our point of view, the algorithm of complex analysis of the functioning of the organizational and economic mechanism of management of agricultural enterprises should be supplemented with indicators of technological and social levels. To this end, to assess the technological efficiency, we will add the following indicators: the volume of gross production per 1 hectare of agricultural land; average daily increase in live weight of cattle and pigs; average annual milk yield per $1 \mathrm{cow}$; yield of cereals and legumes; energy and material intensity of products. To assess social efficiency: the average annual number of organization employees; the average monthly accrued wages of employees of organizations; the amount of taxes and fees paid per 1 agricultural enterprise; the amount of personal income tax paid per 1 employee.

Evaluation of the management mechanism efficiency was carried out using the method of calculating the integral indicator presented in formula 1:

$$
\mathrm{IP}=\sqrt[n]{\mathrm{O} * \mathrm{E} * \mathrm{~T} * \mathrm{C}} \sqrt[n]{\mathrm{O} * \mathrm{E} * \mathrm{~T} * \mathrm{C}}
$$

where IP is an integral indicator of the effectiveness of the mechanism;

$\mathrm{O}$ is an individual indicator of organizational component;

$\mathrm{E}$ is an individual indicator of the economic component;

$\mathrm{T}$ is an individual indicator of the technological component;

$\mathrm{C}$ is an individual indicator of the social component of the mechanism.

$\mathrm{n}$ is the number of levels of the management mechanism, units.

The value of the integral indicator should be greater than one, which will indicate the effective functioning of the mechanism. If the value of the complex indicator does not exceed one, then it is necessary to pay attention to what component (organizational, economic, technological or social) was the reduction of the final result.

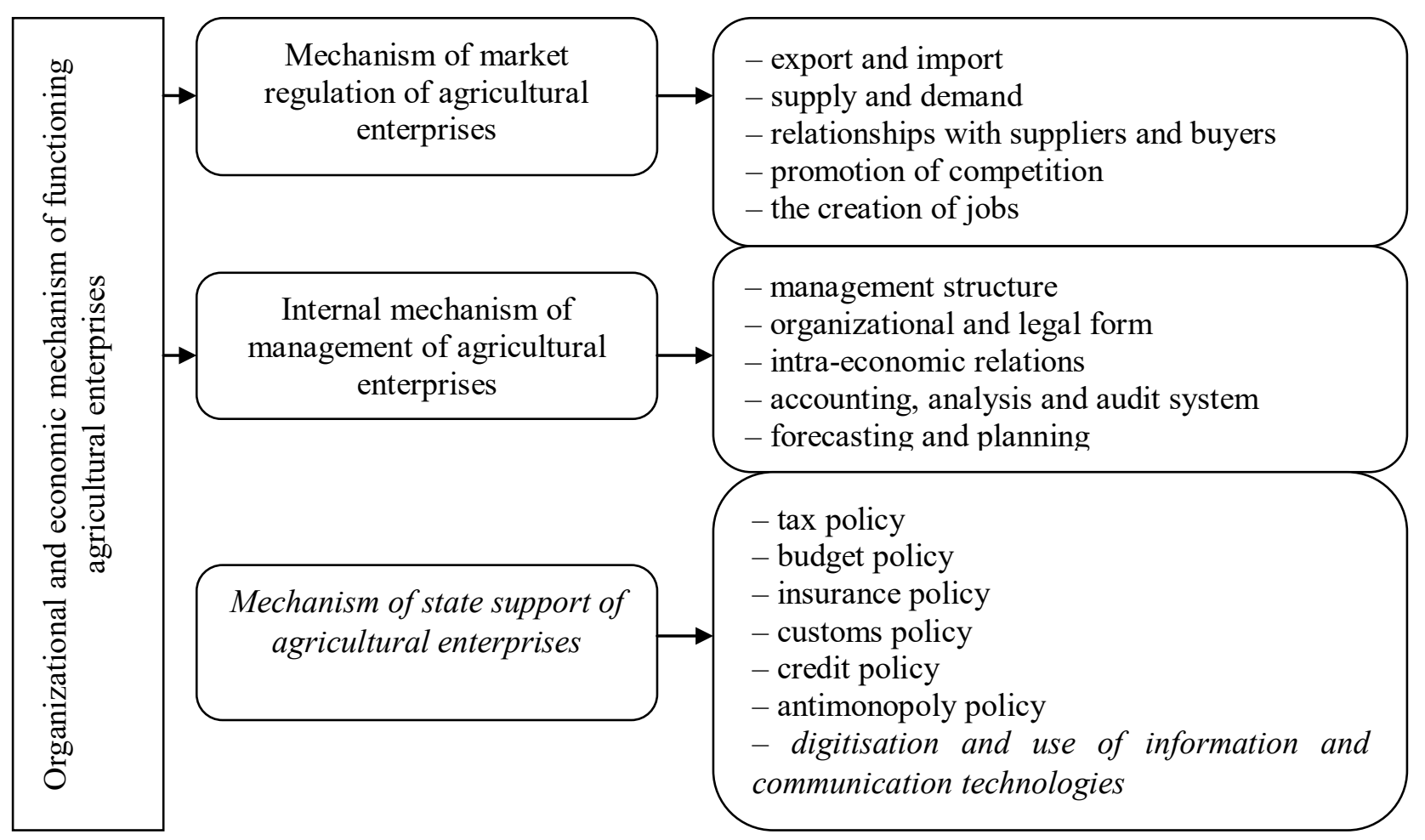

Fig. 1. Scheme of elements of organizational and economic mechanism agricultural enterprise 
Assessment of the organizational and economic mechanism management of agricultural enterprises of the Kurgan region

\begin{tabular}{|l|c|c|c|c|}
\hline \multicolumn{1}{|c|}{ Indicator } & 2016 & 2017 & 2018 & $\begin{array}{c}\text { Growth rate (GR), } \\
2018 \text { to 2016 }\end{array}$ \\
\hline \multicolumn{4}{|c|}{ Economic efficiency of the mechanism } \\
\hline Profit from core activities per employee, & 203647 & 211299 & 290045 & 1.42 \\
\hline Manufactured products per 1 ruble of the wages of workers, rub. & 6.94 & 6.75 & 7.20 & 1.04 \\
\hline Profitability of sales, \% & 15.29 & 14.67 & 16.64 & 1.09 \\
\hline Return of equity capital, \% & 15.96 & 13.6 & 14.92 & 0.93 \\
\hline Return of total capital, \% & 9.25 & 2.99 & 8.67 & 0.94 \\
\hline Absolute liquidity ratio & 0.14 & 0.14 & 0.21 & 1.5 \\
\hline
\end{tabular}

$$
I_{E}=\sqrt[6]{\mathrm{GR}_{1} * \mathrm{GR}_{2} * \ldots * \mathrm{GR}_{6}} \sqrt[6]{\mathrm{GR}_{1} * \mathrm{GR}_{2} * \ldots * \mathrm{GR}_{6}}=\sqrt[6]{1,42 * 1,06} \underset{1, \ldots * 1,5}{6} \sqrt{1,42 * 1,04 * \ldots * 1,5)}
$$

Organizational effectiveness of the mechanism

\begin{tabular}{|l|c|c|c|c|}
\hline Management profitability ratio & 15.78 & 14.92 & 15.93 & 1.01 \\
\hline Capital productivity, rub. & 0.82 & 0.79 & 0.83 & 1.01 \\
\hline Coefficient of renewal of fixed assets & 0.17 & 0.13 & 0.16 & 0.94 \\
\hline Labor productivity, thousand rubles. & 1331.69 & 1440.75 & 1742.63 & 1.31 \\
\hline
\end{tabular}

$$
\begin{aligned}
I_{O}=\sqrt[4]{\mathrm{GR}_{1} * \mathrm{GR}_{2} * \ldots * \mathrm{GR}} \sqrt[4]{\mathrm{fR} \cdot * \mathrm{CR}-* * \mathrm{FR}_{4}}=\sqrt[4]{1,01 * 1,01 * 0,94 * 1,31} & \sqrt[4]{1,01 * 1,01 * 0,94 * 1,31}=1,002 \\
& \text { Technological efficiency of the mechanism }
\end{aligned}
$$

Gross output per 100 hectares of agricultural land, thousand rubles.

The yield of grain and leguminous crops, $\mathrm{kg} / \mathrm{ha}$

Average daily increase in live weight of cattle, grams

Average annual milk yield per $1 \mathrm{cow}, \mathrm{kg}$.

Energy consumption of products $\mathrm{kWh} / \mathrm{rub}$.

Material capacity of products, rub.

\begin{tabular}{|c|c|c|c|}
\hline 956.51 & 1012.72 & 1091.42 & 1.14 \\
\hline 16.6 & 19.7 & 17.3 & 1.04 \\
\hline 550.0 & 546.0 & 469.0 & 0.85 \\
\hline 4184 & 4154 & 4190 & 1.001 \\
\hline 0.004 & 0.004 & 0.004 & 1.00 \\
\hline 1.37 & 1.47 & 0.61 & 0.45 \\
\hline
\end{tabular}

$I_{T}=\sqrt[6]{G R_{1} * \mathrm{GR}_{2} * \ldots * \mathrm{GR}_{6}} \sqrt[6]{G R_{1} * \mathrm{GR}_{2} * \ldots * \mathrm{GR}_{6}}=\sqrt[6]{1,14 * 1,04 * \ldots * 0,45} \sqrt[6]{1,14 * 1,04 * \ldots * 0,45}$ Social effectiveness of the mechanism

Average annual number of employees, people

Average monthly accrued wages of employees of organizations, thousand rubles

Volume of paid insurance premiums per 1 employee, thousand rubles

The amount of personal income tax paid per 1 employee, thousand rubles

\begin{tabular}{|c|c|c|c|}
\hline 7883 & 7510 & 7145 & 0.91 \\
\hline 126072 & 133567 & 144155 & 1.14 \\
\hline 57.96 & 62.14 & 73.72 & 1.27 \\
\hline 26.33 & 28.44 & 32.34 & 1.23 \\
\hline
\end{tabular}

$$
\begin{aligned}
& I_{S}=\sqrt[4]{\mathrm{GR}_{1} * \mathrm{GR}_{2} * \ldots * \mathrm{CR}_{2}} \sqrt[4]{\mathrm{CR}_{\mathrm{R}} * \mathrm{CR}_{2} * * \mathrm{CR}_{\mathrm{R}}}=\sqrt[4]{0,91 * 1,14 * 1,27 * 1,23} \\
& \sqrt[4]{0,91 * 1,14 * 1,27 * 1,23}=0,977
\end{aligned}
$$

$$
I I=\sqrt[4]{1,06 * 1,002 * 1,022 * 0,997} \sqrt[4]{1,06 * 1,002 * 1,022 * 0,997}=1,015
$$

Note: compiled according to the Department of agriculture of the Kurgan region

The calculation of individual indicators is presented in formula 2 :

$$
\mathrm{I}_{\mathrm{m}}=\sqrt[\mathrm{n}]{\mathrm{TR}_{1} * \mathrm{TR}_{2} * \ldots * \mathrm{TR}_{\mathrm{n}}}
$$

where $\mathrm{I}_{\mathrm{m}}$ is an individual indicator of the effectiveness of the organizational, economic, technological and social component of the mechanism;

TR is a growth rate of indicators; $\mathrm{n}$ is the number of indicators, units.

The calculations of individual parameters of efficiency of organizational and economic mechanism of management of agricultural enterprises of Zauralya and the value of the integral indicator for the period 2016-2018 are presented in table 2.

As a result of the analysis, the obtained integral indicator of the assessment of the organizational and economic mechanism of management of agricultural organizations of the Zauralya is more than one, which indicates its effectiveness, however, there are difficulties with the implementation of the social component of the mechanism of management, associated, in many respects, with a sharp decline in the number of agricultural workers. 


\section{Discussion and Conclusion}

Issues of studying the formation and evaluation of the organizational and economic mechanism of the agricultural industry has always been given a special role, since the success of its functioning, in many respects, depends on the conscious use of economic and organizational levers of influence on agricultural production.

In a comprehensive study of the formation and analysis of the effectiveness of the organizational and economic mechanism of regional agriculture development, the leading role is played by the state. Therefore, the organizational-economic mechanism of the agrarian sector of the meso- and micro-level in terms of market transformation must include elements of state regulation and support of the industry, the internal management of enterprises and account for the action of market laws. It should be noted that the developed system of agrarian policy for the implementation of the organizational and economic mechanism should be built taking into account modern features of agricultural production, that is, include additional levers of organizational and economic impact.

The development of agriculture of the Kurgan region, where some difficulties have been observed in recent years, is the key to the successful formation and functioning of the organizational and economic mechanism of management of farmers. That is why, one of the tasks is to develop a model for assessing the effectiveness of such a mechanism, taking into account all the features of agricultural production. In the study, the author proposes an integrated assessment model of the efficiency of organizational-economic mechanism of management of farmers of Zauralya, according to which not only meaningful elements reveals but the peculiarities of their formation at the regional level are found out.

\section{References}

1. Khodos D. V., Ivanov S. G., D’yachenko O. G. Ekonomicheskiy mekhanizm razvitiya APK regiona [Economic mechanism of development of agribusiness in the region] // The Bulletin of KrasGAU. 2013. No. 12 (87). Pp. 24-28. (In Russian.)

2. Semin A. N. Nauchnyye osnovy formirovaniya ekonomicheskikh mekhanizmov: formy, tipy, vidy [Scientific bases of formation of economic mechanisms: forms, types, types] // Agro-food policy in Russia. 2012. No. 5. Pp. 5-12. (In Russian.) 3. Mitin A. N. Analiz nauchnykh vzglyadov o ponyatii "ekonomicheskiy mekha-nizm" i ego modifikatsiyakh v agrarnoy sfere ekonomiki [Analysis of scientific views on the concept of "economic mechanism" and its modifications in the agricultural sector of the economy] // Agrarnoe obrazovanie i nauka. 2016. No. 4. Pp. 112-118. (In Russian.)

4. Popova L. V., Korobeynikov D. A., Korobeynikova O. M., Batmanova V. V. Organizatsionno-ekonomicheskiy mekhanizm ovoshchevodstva otkrytogo grunta [Organizational and economic mechanism of open-ground vegetable growing] // Economics: Yesterday, Today and Tomorrow. 2016. No. 7. Pp. 301-314. (In Russian.)

5. Gorbunov Yu. V. O ponyatii "mekhanizm" v ekonomicheskikh naukakh [About the concept of "mechanism" in economic sciences] // Economics Profession Business. 2018. No. 2. Pp. 17-21. (In Russian.)

6. Vereshchagina L. S. O soderzhanii organizatsionno-ekonomicheskogo mekha-nizma upravleniya promyshlennym predpriyatiyem [About the content of organizational and economic mechanism of industrial enterprise management] // Vestnik of Saratov State Socio-Economic University. 2011. No. 2 (36). Pp. 60-63. (In Russian.)

7. Hurwicz L. But who will guard the guardians? [e-resource] // Nobel prize lecture. December 8. 2007. URL: http://citeseerx. ist.psu.edu/viewdoc/download?doi=10.1.1.362.5440\&rep=rep1\&type=pdf (appeal date: 27.11.2019).

8. Golubeva A. I., Mantsevich I. V. Organizatsionno-ekonomicheskiy mekhanizm gosudarstvennogo regulirovaniya deyatel'nosti sel'skokhozyaystvennykh predpriyatiy regiona: monografiya [Organizational and economic mechanism of state regulation of agricultural enterprises in the region: monograph]. Yaroslavl', 2011. 290 p. (In Russian.)

9. Korsak M. M., Surdo A. P. Formirovaniye kontseptual'noy modeli organizatsionno-ekonomicheskogo mekhanizma upravleniya [Formation of conceptual model of organizational and economic mechanism of management] // University Economic Bulletin. 2018. No. 37-1. Pp. 90-96. (In Russian.)

10. Averina I. S. Evolyutsiya i klassifikatsiya fenomena "khozyaystvennyy me-khanizm" [Evolution and classification of the phenomenon "economic mechanism"] // Journal of Volgograd State University. Economics. 2012. No. 2 (21). Pp. 12-16. (In Russian.)

11. Kholodkova K. S. Analiz podkhodov k opredeleniyu sushchnosti organizatsi-onno-ekonomicheskogo mekhanizma upravleniya [Analysis of approaches to determining the essence of the organizational and economic mechanism of management] // Modern scientific researches and innovations. 2016. No. 5 (61). Pp. 213-221. (In Russian.)

12. Zhdanov V. V. Faktory, vliyayushchiye na organizatsionno-ekonomicheskiy mekhanizm obespecheniya platezhesposobnosti [Factors influencing the organizational and economic mechanism of ensuring solvency] // Bulletin of Altai State Agricultural University. 2007. No. 2 (28). Pp. 81-84. (In Russian.)

13. Gorbunova O. S. Sovremennoye nauchnoye predstavleniye ob effektivnosti ekonomicheskogo mekhanizma khozyaystvovaniya [Modern scientific understanding of the efficiency of the economic mechanism of management] // Agrarian Bulletin of the Urals. 2013. No. 3 (109). Pp. 55-59. (In Russian.)

14. Belikova N. A. Organizatsionno-ekonomicheskiy mekhanizm pitomnikovodstva: ponyatiye i osnovnyye elementy [Organizational and economic mechanism of nursery: the concept and basic elements] // APC: economy, management. 2009. No. 6. Pp. 10-11. (In Russian.)

15. Medvedeva T. N., Artamonova I. A., Baturina I. N. Gosudarstvennaya pod-derzhka malogo biznesa v sel'skom khozyaystve Zaural'ya [State support of small business in agriculture of the Zaural'ye] // Sovremennaya ekonomika: obespecheniye 
prodovol'stvennoy bezopasnosti: materialy V Vserossiyskoy nauchno-prakticheskoy konferentsii. Kinel', 2018. Pp. 129-132. (In Russian.)

16. Department of the Federal State Statistics Service of the Kurdistan region [e-resource]. URL: http://www.gks.ru (appeal date: 28.11.19).

17. Semin A., Kibirov A., Rassukhanov U. Problems and main mechanism-isms to increase investment attractiveness of agricultural production // European Research Studies Journal. 2018. No. 21 (2). Pp. 378-400.

18. Sharapova N. V., Sharapova V. M. Program-Targeted Management of the Agricultural Sector // Proceedings of the 32nd International Business Information Management Association Conference, IBIMA 2018 - Vision 2020: Sustainable Economic Development and Application of Innovation Management from Regional expansion to Global Growth. 2018. Seville, Spain. Pp. 5455-5458.

19. Pustuyev A. L., Stepanov F. A. Ekonomicheskiy mekhanizm ustoychivosti v sisteme upravleniya APK [The Economic mechanism of stability in the management system of agriculture] // Agrarian Bulletin of the Urals. 2008. No. 12 (54). Pp. 3132. (In Russian.)

20. Donnik I., Voronin B., Loretts O. Production of organic agricultural products is an Important area of "green" economy // Indian Journal of Science and Technology. 2016. Vol. 9 (14). P. 91512.

21. Korobeynikov D. A., Telitchenko D. N. Organizatsionno-ekonomicheskiy mekhanizm funktsionirovaniya ovoshchevodstva otkrytogo grunta [Organizational and economic mechanism of functioning of open-ground vegetable growing] // Actual problems of Humanities and Socio-economic Sciences. 2014. No. 3. Pp. 34-40. (In Russian.)

22. Mikov K. A., Pytkina S. A. Kontseptual'nyye aspekty organizatsionno-ekonomicheskogo mekhanizma programmirovaniya razvitiya agropromyshlennogo kompleksa [Conceptual aspects of the organizational and economic mechanism of programming the development of agro-industrial complex] // The Russian Journal of Entrepreneurship. 2012. No. 9 (107). Pp. 118-122. (In Russian.)

23. Medvedeva T. N., Borovinskikh V. A. Determinanty khozyaystvovaniya predpriyatiy agrarnoy otrasli [Determinants of management of enterprises of the agrarian sector] // APC: regions of Russia. 2012. No. 4. Pp. 8-11. (In Russian.)

24. Ginter E. V. Organizatsionno-ekonomicheskiy mekhanizm khozyaystvovaniya v agrarnom sektore Magadanskoy oblasti i otsenka ego effektivnosti [Organizational and economic mechanism of management in the agricultural sector of the Magadan region and evaluation of its effectiveness] // Economics and Management. 2017. No. 10. Pp. 42-46. (In Russian.)

\section{Authors' information:}

Evelina A. Farvazova1, postgraduate, ORCID 0000-0003-1134-9294, AuthorID 1021997; linulya07@mail.ru, +7 919 595-65-11

${ }^{1}$ Ural State Agrarian University, Ekaterinburg, Russia 